\title{
Editorial
}

\section{ITET: A Venue for Mentoring and Sponsoring Graduate Students in the Digital Age}

\author{
Betül C. Czerkawski \\ Editor, ITET
}

\begin{abstract}
When I started ITET, one of the major goals I had in mind was to create a graduate student friendly journal. 'Friendly,' in this sense, meant an editorial staff working closely with students to turn their distinguished term papers into publishable, quality manuscripts. Why is this a 'friendly' approach for graduate students? More than ever, today's graduate students need quality mentorship in writing, in scholarship, and in publishing. Our intention at ITET is obviously not to fill a void in all aspects of mentorship and sponsorship but to help students gain some exposure to academic publishing and amass more experience in writing research papers while they grow as scholars.
\end{abstract}

Keywords: graduate students; mentoring; sponsorship; professional networking

When I started ITET, one of the major goals I had in mind was to create a graduate student friendly journal. 'Friendly,' in this sense, meant an editorial staff working closely with students to turn their distinguished term papers into publishable, quality manuscripts. Instead of evaluating these papers through our peer review system, as we do for our other submissions, we created a new category for graduate students only, clearly separated from the peer reviewed papers, and then worked closely with students to develop their papers. Since implementing this approach, many exchanges have occurred between our editorial team and graduate student authors. While most editorial teams work with authors to improve their papers, I am not aware of any other journal that does such extensive work with the authors as ITET. I must admit that this is a very time-consuming and labor-intensive job. However, I get excellent help from our past and present managing editors, Max, Gene, and Nicole, all of whom are graduate students. We have integrated this 'graduate student friendly' practice for about four years, and we plan to continue our approach, even if that means publishing fewer manuscripts due to time constraints.

Why is this a 'friendly' approach for graduate students? More than ever, today's graduate students need quality mentorship in writing, in scholarship, and in publishing. Only a decade ago, the number of online and blended courses in graduate programs was sparse, and students spent more time with their professors, learning the fundamentals of their 
discipline. New digital technologies and growing interest in online degree programs has advanced many facets of higher education, but it has also significantly altered mentormentee relationships, as we know them. Some even argue that current adjunctification of academia, workplace shifts, and technological disruption have put academic mentormentee relations in peril (Read, 2013).

In addition to the recent need for new types of mentoring in academia, there is also another piece of the puzzle that needs more attention, and that is sponsorship. Mentoring and sponsoring are complimentary, but just like the changing nature of mentoring practices, sponsoring also has new implications. First, we have to describe the major difference between these terms: sponsorship for graduate students goes beyond mentoring or dissertation advising. In sponsorship, the professors proactively seek opportunities to involve their students in research studies and grant work, offer them opportunities for teaching, and integrate them into the larger community of scholars. They help their students to lay a foundation for future connections and networkingopportunities. In today's academia, networking is not limited to attending conferences to meet with new peers; it also requires making connections through a range of diverse professional activities.

Professors also assist their students so that they can increase their visibility as junior scholars within and outside of their own institutions. Writing reference letters for students and offering a good word in job applications definitely count for sponsorship, but these activities are more in line with traditional ways of sponsoring graduate students. In the age of digital technologies, personal learning environments and virtual, global, and collaborative networks, there are different ways to promote a student. Depending on the career goals of the students and their disciplinary strands, professors should employ different strategies after carefully reflecting on overall promotion techniques. In the new sponsorship era, students also have responsibilities, and first among them is the understanding that they cannot solely rely on a sponsor or a professor to jumpstart their careers.

The type of sponsorship I describe here may require years of cultivating a partnership in which professors and students know each other's strengths and weaknesses and develop a mutual understanding as the basis of their collaboration. Hopefully, this mentorship and sponsorship is also an evolving relationship (as we all know, this does not happen all the time) so that over time when students start establishing themselves as scholars in their respective fields, the mentor and mentee become colleagues.

Our intention at ITET is obviously not to fill a void in all aspects of mentorship and sponsorship but to help students gain some exposure to academic publishing and amass more experience in writing research papers while they grow as scholars. Furthermore, ITET's editors can fulfill some of the roles of mentorship from the publishing world. By encouraging and helping a graduate student to publish in ITET, a mentor is also 
supporting their mentee's first steps into a new professional network. This is our call to the professors out there to consider our journal a new venue to support their graduate students.

\section{Reference}

Read, B. (2013). Is mentorship in peril? ChronicleVitae. https://chroniclevitae.com/ news/167-is-mentorship-in-peril. 